\title{
The Extent of Customers' Use of Online Booking Applications within Airlines Organizations
}

\author{
Fahed Al Duwailah $^{{ }^{*} \quad \text { Redjem Khaled }}{ }^{2}$ \\ 1.National Security College, Salam, Kuwait \\ 2.University Kasdi Merbah, Ouargla, Algeria
}

\begin{abstract}
Current study aimed at examining customers' intention to use online booking applications that are developed and promoted by airlines in Kuwait through the year 2019. A convenient sample of (585) individuals was chosen to be the main sample of study. After the distribution process a total of (500) properly filled questionnaire were retrieved giving an indication of $85.4 \%$ response rate. The questionnaire consisted of two main sections, the first took into perspective the demographic variables of respondents (age, gender, qualifications, computer literacy), while the other section consisted of statements related to the independent variable (Site Features, Information, Accessibility, Communication, Reliability, Trust, Responsiveness, and Personalization). Results of study indicated that website features and trust are the most important quality indicators that influence customers' intention to use e-ticketing. Study recommended to give extra attention to website designs and features I terms to keep it simple and rich at the same time. In addition to that, it is important to keep clients informed regarding the degree of security that the website enjoys, as it is one of the most important aspects in increasing individuals' intention to use an e-service of any kind.
\end{abstract}

Keywords: E-service, Online Booking, Airlines, E-Service Quality, Customers, Kuwait

DOI: $10.7176 / \mathrm{EJBM} / 12-12-10$

Publication date: April $30^{\text {th }} 2020$

\section{Introduction}

Internet and technology are developing in a fast pace. Now, almost all of our activities can be done online without the need to move from a place to another. One of the sectors that gained many benefits from internet and technology is airline organizations which started to depend on social media and online application in an extensive away during the last decade. Many organizations within the airline industry have exploited many individuals' acceptance of online service and the convenience that comes with it in promoting for its services online and building applications that can support customers' needs without them leaving their living room (Abdullateef et al., 2018).

The current era in which we live increases the information around us and increases our use of and reliance on this information in our daily lives. This is evident in the wide growth of the Internet and our increasing reliance on e-mail and services provided by web sites (Weinelt and Moavenzadeh, 2017). To take advantage of this technology in all fields, including the administrative areas to get rid of traditional management, electronic management is an effective input to the recognition of the nature of the paper in all administrative processes and to give the electronic nature to the extent of granting a service to beneficiaries and then meet their requirements through various means (Clemes et al., 2008).

\section{Problem Statement}

According to Kim et al. (2017) the idea of e-service in general is attributed to the degree of trust and the level of quality that are received by the customer through online services are among the concepts that help in developing a good intention to use the service online one more. Also, Alatawy (2015) noted to the fact that the online service must enjoy a higher level of quality compared to the regular service given that it is being granted through the web and its quality is among the things that should convince customers to have more trust and ability to use it. Bahari et al. (2018) argued that since the online service is something that is abstract and granted from distance; then there is a need to increase its efficiency starting with the website and its features like style, themes, colors and design, in addition to the accessibility of the website and the level of ease of use; those are among the factors that influence the individuals' experience in booking a ticket, renting a car or finding a room in a hotel.

Based on the above argument, current study sought to examine the influence of e-service quality indicators (Site Features, Information, Accessibility, Communication, Reliability, Trust, Responsiveness, and Personalization) in increasing individuals' intention to use e-ticketing service in Kuwait.

Study developed the following hypotheses:

H: E-service Quality Indicators positively influences the customers' intention to use online booking applications.

H1: Site Features positively influences the customers' intention to use online booking applications.

H2: Information positively influences the customers' intention to use online booking applications.

H3: Accessibility positively influences the customers' intention to use online booking applications.

$\mathrm{H} 4$ : Communication positively influences the customers' intention to use online booking applications. 
H5: Reliability positively influences the customers' intention to use online booking applications.

H6: Trust positively influences the customers' intention to use online booking applications.

H7: Responsiveness positively influences the customers' intention to use online booking applications.

H8: Personalization positively influences the customers' intention to use online booking applications.

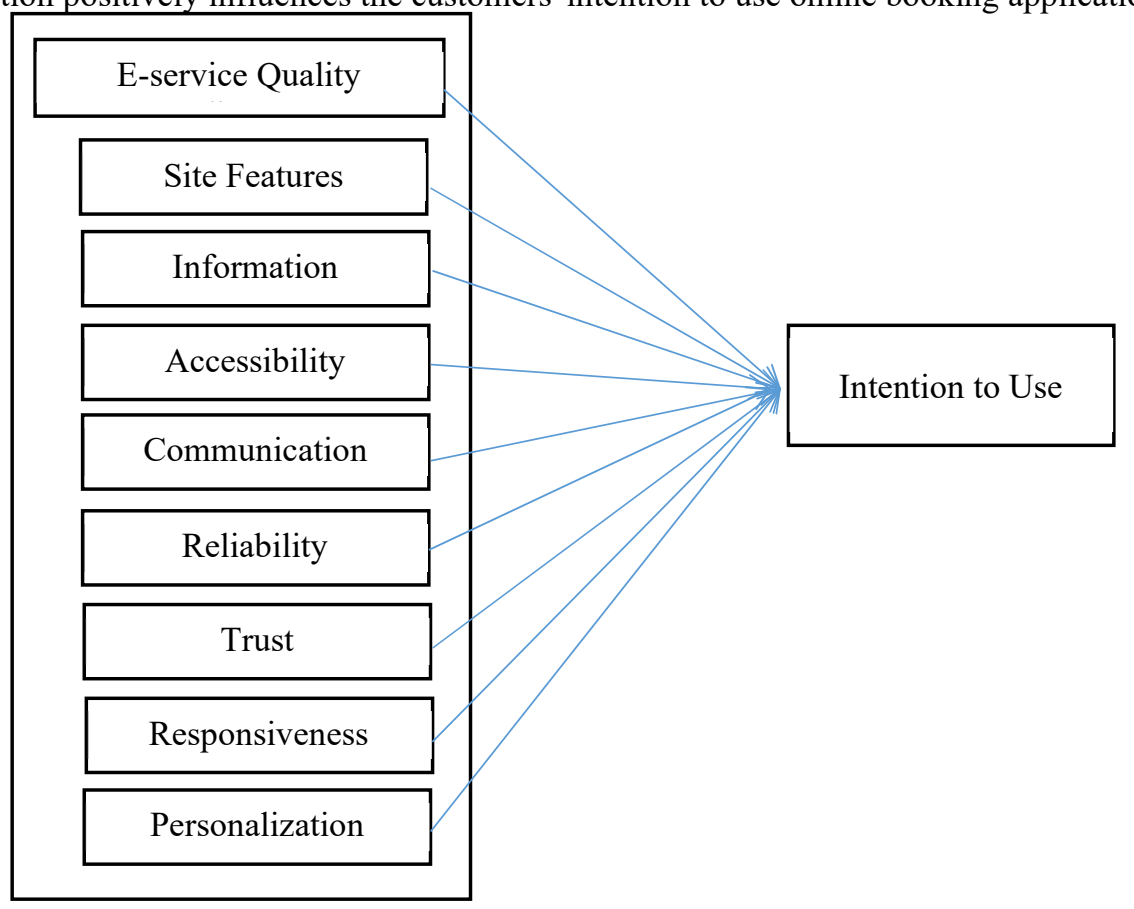

Figure 1: Study Model

\subsection{Literature Review}

\subsection{E-Service Quality}

The electronic service (E-service) in its narrow framework can be defined as a service that involves information services and services through websites, and many IT infrastructure companies in the telecommunications sector are seen as providing electronic services such as networking, shopping, booking, consulting and education. The electronic service relates to the service offered to the consumer in the presence of an intermediary is an electronic network, and supports the decision to buy electronic. E-service is a form of self-service that requires the customer to do the same service, instead of asking the employee behind the office or talking to someone over the phone for information or inquiries, the service is obtained through automated interaction between the service applicant and the machine.

The design of an e-service should be based on customer needs, desires, expectations and expectations. An example of this was electronic publishing. At the beginning of this service, the publications appeared in a format that was not at all flexible, especially in terms of the difficulty of downloading the newspaper or magazine. However, over time, software technologies were introduced that allowed the content to be displayed easily and with great flexibility. The right of the customer and to meet the most accurate desires needs and aspirations determine the relationship and to provide this service must be available a set of standards and are as follows:

- $\quad$ E-service should be fast and prompt.

- Slow servers, delays and connection are important to define the nature and ability of an e-service to satisfy customers.

- $\quad$ Reliability is a factor of e-service and it should have the ability to be compatible with other servers and devices.

\subsection{E-Service Quality Indicators}

\subsubsection{Site Features}

This aspect is very important; the way a website looks plays a role in defining users' satisfaction towards it. When saying the looks of a website, it is meant the interface, design, themes, colors, platform and overall options of the website are easy to handle and use, accessible and attractive. Attraction does not mean for it to be very colorful all complex, it must be a type of a design that helps users browse the website without any hardness (Al-Hawary et al. 2016).

\subsubsection{Information}

Just like any other service, information is important to keep customers' informed regarding the service from its 
beginning to the end. When it comes to e-services, information means the ability of the service provider to inform the customer with all the needed information without the customer having to call a certain number or contact an employee for more queries (Nath and Zheng, 2004).

\subsubsection{Accessibility}

Also means approachability, the service is easy to, use, easy to be done and not complicated, it can be understood and done by any individual who has the slightest experience in technology and it can provide the needed results within the previously set time. Beneke et al (2011) noted that an e-service to be described as accessible then the steps of the service have to be easy to memorize from individuals and query regarding the service is reachable and activated.

\subsubsection{Communication}

This indicator is very important as it involves a lot of dimensions; from one side it may refer to the speed and courtesy of operators and service providers to meet customers" expectation though using multiple language that meet their abilities and enable them to get the most of the service (Beneke et al., 2011).

\subsubsection{Reliability}

This dimension refers to the service ability to be done from the first time, it is dependable and the organization which provides the service has the ability to keep its promises. In addition to that, reliability means accurate billing and paying services for the e-service which is based on zero errors (AlBalushi et al., 2016).

$$
\text { 3.2.6 Trust }
$$

This dimension is a key issue here. Trust is way important than other dimensions especially for services that are provided online and needs to be paid also online. Trust is one of the most important factors that help in increasing the intention of customers to use an online paid service especially for a service like booking a hotel room of a plane ticket. It involves a lot to do with giving and handing out financial information and credit cards numbers which are sensitive for many individuals (Beneke et al., 2011).

\subsubsection{Responsiveness}

When saying that a certain e-service is responsive; then it means that it takes no time to be done and it can be dine promptly without any kind of delay. Also, a responsive service mean to get back to the customer immediately answer question with no delay and deliver the service in the best shape possible (Swaid et al., 2009).

\subsubsection{Personalization}

This dimension doesn't seem to be as important as other dimensions. The idea of personalization means to give customers an individual attention to them through special discounts, thank you notes and invitations for different event that are related to the organization. Not so many people care that much of the issue of personalization, as they prefer to get their service in the best way possible and then move on with their lives. Al Balushi et al. (2016)

\section{E-Service within Airline Organizations (E-Ticketing)}

The booking was used for storage, querying and booking of travel. Initially used by airlines and then extended for use by travel agencies, airlines granted electronic booking to specialized global distribution companies, which allow customers to book online Hotels and car rental in addition to travel tickets and train tickets in some countries. It also facilitates the process of changing the flight line and comparing the prices of services among them, in addition to a graphical interface for seats to facilitate the temporary booking (Kurniawan, 2010).

Al-Refaie et al. (2014) pointed out that electronic booking is the process of booking service tickets, although it is very much related to the field of tourism, travel, hotel and transportation. A study has announced that more than a third of the volume of electronic commerce between companies and consumers will go to online booking operations for flights and hotels to reach $24 \%$ of the total e-commerce transactions between companies and individuals. Byambaa and Chang (2012) expected to increase the share of the travel sector and hotels in this area to reach $32 \%$ by the end of 2008. Malagas et al. (2013) argued that the process of electronic booking of tickets is simple, by telephone or via the Internet and the company provides travel information and the number of its credit card, and then get the number of the booking or printing and the traveler to go to the airport and shows the official confirmation number of the reservation and then delivered his luggage and receive the card of boarding the plane and in the absence of luggage, the process occurs electronically enter the registration number in a special machine and receive the boarding card.

Qteishat et al. (2014) saw that it seems that this does not stop at this limit, but even in some developed countries to provide self-service ticket issuance through the traveler personally using a credit card and electronic payment system and pay the value of the ticket electronically and then get it from any place to choose, as well as to book hotels, The efficient user of the site not only knows where the hotel wants to go or shape, he also wants to know the price of rooms as well as the number of empty rooms that can be booked.

\section{Methods}

Current study employed the quantitative approach in order to realize the previously presented hypotheses. A questionnaire was adopted in order to be the main tool of study. the questionnaire consisted of two sections; the 
first was concerned with the demographics variables of study (gender, age, education, job, experience in e-ticketing and income) while the other section presented statements which were related to the main variables of study (Site Features, Information, Accessibility, Communication, Reliability, Trust, Responsiveness, and Personalization). Eticketing customers were the population of study; a convenience sample of (585) individuals was chosen to be exposed to the questionnaire. After the distribution process, researcher was able to retrieve (500) properly filled questionnaire referring to $85.4 \%$ response rate which was statistically accepted.

In order to test the reliability of study tool; Cronbachs' alpha was used and it showed that all items scored (0.965) which appeared to be higher than 0.60 indicating the tool consistency that enhanced its use for the study. Following SPSS tests were employed:
- Descriptive Statistic
- $\quad$ Linear Regression
- Multiple Regression
- Cronbach's Alpha

\section{Results and Discussion}

Bearing in mind that questionnaire used in current study consisted of two sections; demographics and statements of questionnaire, SPSS was run in order to highlight sample characteristics according to demographics which included (gender, age, educational level, job, experience and income.

Results of study indicated that majority of the sample (69.6\%) were males forming 348 individuals while females appeared to take $30.4 \%$ of the whole sample. Regarding age, more than half of the sample aged between $34-39$ years old forming $56.2 \%$ followed by $22 \%$ with age range of $22-27$ years old. Also, analysis showed that $55 \%$ of the sample had the bachelor degree and $58.6 \%$ of the sample worked within the public sector. At the same time, $39 \%$ of the sample has used e-ticketing service 3-4 times in one year while $53.4 \%$ of the sample had income of more than 2000 KWD.

Table 1: Sample Characteristics According to Demographics

\begin{tabular}{|c|c|c|c|c|}
\hline \multicolumn{5}{|c|}{ Gender } \\
\hline & Frequency & Percent & Valid Percent & Cumulative Percent \\
\hline Male & 348 & 69.6 & 69.6 & 69.6 \\
\hline Female & 152 & 30.4 & 30.4 & 100.0 \\
\hline Total & 500 & 100.0 & 100.0 & \\
\hline \multicolumn{5}{|c|}{ Age } \\
\hline & Frequency & Percent & Valid Percent & Cumulative Percent \\
\hline $22-27$ & 110 & 22.0 & 22.0 & 22.0 \\
\hline $28-33$ & 86 & 17.2 & 17.2 & 39.2 \\
\hline 34-39 & 281 & 56.2 & 56.2 & 95.4 \\
\hline+40 & 23 & 4.6 & 4.6 & 100.0 \\
\hline Total & 500 & 100.0 & 100.0 & \\
\hline \multicolumn{5}{|c|}{ Educational Level } \\
\hline & Frequency & Percent & Valid Percent & Cumulative Percent \\
\hline Diploma & 18 & 3.6 & 3.6 & 3.6 \\
\hline $\mathrm{BA}$ & 275 & 55.0 & 55.0 & 58.6 \\
\hline MA & 125 & 25.0 & 25.0 & 83.6 \\
\hline $\mathrm{PhD}$ & 82 & 16.4 & 16.4 & 100.0 \\
\hline Total & 500 & 100.0 & 100.0 & \\
\hline \multicolumn{5}{|c|}{ job } \\
\hline & Frequency & Percent & Valid Percent & Cumulative Percent \\
\hline Public & 293 & 58.6 & 58.6 & 58.6 \\
\hline Private & 86 & 17.2 & 17.2 & 75.8 \\
\hline Self-employed & 79 & 15.8 & 15.8 & 91.6 \\
\hline House wife & 42 & 8.4 & 8.4 & 100.0 \\
\hline Total & 500 & 100.0 & 100.0 & \\
\hline \multicolumn{5}{|c|}{ Experience in Using E-Ticketing } \\
\hline & Frequency & Percent & Valid Percent & Cumulative Percent \\
\hline 0 year & 19 & 3.8 & 3.8 & 3.8 \\
\hline $1-2 /$ year & 184 & 36.8 & 36.8 & 40.6 \\
\hline $3-4 /$ year & 195 & 39.0 & 39.0 & 79.6 \\
\hline$+5 /$ year & 102 & 20.4 & 20.4 & 100.0 \\
\hline
\end{tabular}




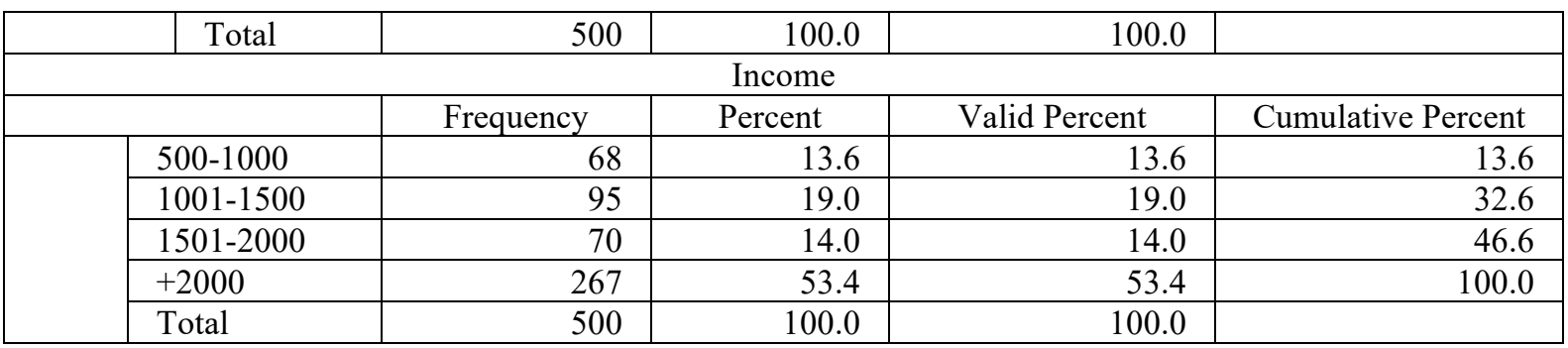

As for analyzing the second section of the questionnaire which presented sample responses to the variables' statements; it appeared that there was a positive attitude towards statements of questionnaire as all of statements scored higher than the mean of scale 3.00 referring to a positive attitude and high awareness of respondents towards all statements.

Table 2: Variables' Statements Analysis

\begin{tabular}{|c|c|c|c|c|c|}
\hline & $\mathrm{N}$ & Minimum & Maximum & Mean & $\begin{array}{l}\text { Std. } \\
\text { Deviation }\end{array}$ \\
\hline \multicolumn{6}{|c|}{ Intention to Use } \\
\hline $\begin{array}{l}\text { I prefer online booking as it is easier and saves time and } \\
\text { efforts }\end{array}$ & 500 & 1 & 5 & 4.06 & 1.148 \\
\hline $\begin{array}{l}\text { I prefer to deal with organizations that provides online } \\
\text { services }\end{array}$ & 500 & 1 & 5 & 4.07 & .985 \\
\hline $\begin{array}{l}\text { I can follow an initial booking online but never give my } \\
\text { financial information on a website }\end{array}$ & 500 & 1 & 5 & 4.05 & 1.123 \\
\hline $\begin{array}{l}\text { All website can be easily hacked so I don't trust online } \\
\text { booking services }\end{array}$ & 500 & 1 & 5 & 4.08 & 1.095 \\
\hline $\begin{array}{l}\text { Online booking prevent me from facing any surprises } \\
\text { along the way }\end{array}$ & 500 & 1 & 5 & 4.03 & .969 \\
\hline \multicolumn{6}{|c|}{ E-Service Quality Indicators } \\
\hline \multicolumn{6}{|c|}{ Site Features } \\
\hline Website is attractive and user friendly & 500 & 1 & 5 & 3.99 & 1.151 \\
\hline There are visual helping aids & 500 & 1 & 5 & 4.18 & 1.037 \\
\hline It is easy to memorize the website address & 500 & 1 & 5 & 4.12 & 1.037 \\
\hline $\begin{array}{l}\text { The website isn't complicated and ban be traced and } \\
\text { used easily }\end{array}$ & 500 & 1 & 5 & 4.08 & .964 \\
\hline $\begin{array}{l}\text { Website has a good search system that eases the process } \\
\text { to find the information }\end{array}$ & 500 & 1 & 5 & 3.87 & 1.040 \\
\hline \multicolumn{6}{|c|}{ Information } \\
\hline Contact information are all available on the website & 500 & 1 & 5 & 3.85 & 1.032 \\
\hline $\begin{array}{l}\text { There are local information as well as international } \\
\text { information center }\end{array}$ & 500 & 1 & 5 & 3.85 & .976 \\
\hline Website is available in all universal languages & 500 & 1 & 5 & 3.98 & 1.089 \\
\hline $\begin{array}{l}\text { There are lots of option on the website to gain the } \\
\text { information that one needs }\end{array}$ & 500 & 1 & 5 & 3.81 & 1.041 \\
\hline All information are accurate and up-to-date & 500 & 1 & 5 & 3.93 & 1.028 \\
\hline Web site provides useful and reliable information & 500 & 1 & 5 & 3.91 & .992 \\
\hline \multicolumn{6}{|c|}{ Accessibility } \\
\hline I am able to complete a transaction quickly & 500 & 1 & 5 & 3.81 & .960 \\
\hline The service is always working without delay & 500 & 1 & 5 & 3.79 & 1.025 \\
\hline $\begin{array}{l}\text { there a mobile application for the website that I can use } \\
\text { from my mobile }\end{array}$ & 500 & 1 & 5 & 3.79 & 1.095 \\
\hline \multicolumn{6}{|c|}{ Communication } \\
\hline $\begin{array}{l}\text { A user can connect the service wither in the phone, } \\
\text { email or on both of them }\end{array}$ & 500 & 1 & 5 & 3.77 & 1.025 \\
\hline $\begin{array}{l}\text { There are operators who speak universal languages for } \\
\text { help }\end{array}$ & 500 & 1 & 5 & 3.93 & .985 \\
\hline $\begin{array}{l}\text { E-mails or questionnaires are used to conduct customer } \\
\text { satisfaction surveys }\end{array}$ & 500 & 1 & 5 & 4.03 & 1.046 \\
\hline
\end{tabular}




\begin{tabular}{|c|c|c|c|c|c|}
\hline $\begin{array}{l}\text { Customers might be reminded electronically to } \\
\text { repurchase and be invited to special offers, etc. }\end{array}$ & 500 & 1 & 5 & 3.98 & 1.021 \\
\hline \multicolumn{6}{|c|}{ Reliability } \\
\hline The service is reliable and enjoys a good security level & 500 & 1 & 5 & 4.08 & 1.107 \\
\hline $\begin{array}{l}\text { It is rarely to face connection problems with the service } \\
\text { and on the website }\end{array}$ & 500 & 1 & 5 & 4.05 & 1.057 \\
\hline The website and service providers are available $24 / 7$ & 500 & 1 & 5 & 4.20 & 1.092 \\
\hline $\begin{array}{l}\text { The website sends prompt messages for extra } \\
\text { information }\end{array}$ & 500 & 1 & 5 & 4.10 & 1.070 \\
\hline \multicolumn{6}{|c|}{ Trust } \\
\hline Service providers guarantee privacy policy on its site & 500 & 1 & 5 & 4.16 & 1.023 \\
\hline Service providers can convey trust and confidence & 500 & 1 & 5 & 4.08 & 1.049 \\
\hline I trust the website for my credit card information & 500 & 1 & 5 & 4.19 & .974 \\
\hline $\begin{array}{l}\text { Never seen any complain on the service providers } \\
\text { through social media }\end{array}$ & 500 & 1 & 5 & 4.17 & 1.059 \\
\hline \multicolumn{6}{|c|}{ Responsiveness } \\
\hline $\begin{array}{l}\text { Service providers can provide the promised service } \\
\text { carefully and consistently /stable. }\end{array}$ & 500 & 1 & 5 & 4.15 & .948 \\
\hline $\begin{array}{l}\text { There is a concrete person to contact in case of trouble } \\
\text { and malfunction in the service }\end{array}$ & 500 & 1 & 5 & 3.98 & 1.149 \\
\hline $\begin{array}{l}\text { Service provider has a good ability to answer questions } \\
\text { and solve problems }\end{array}$ & 500 & 1 & 5 & 4.13 & 1.055 \\
\hline Employees on the operating section is helpful and nice & 500 & 1 & 5 & 4.12 & 1.119 \\
\hline $\begin{array}{l}\text { Service providers answers quickly when I call or write } \\
\text { e-mail }\end{array}$ & 500 & 1 & 5 & 4.11 & .991 \\
\hline Service providers delivers orders when promised & 500 & 1 & 5 & 3.85 & 1.080 \\
\hline \multicolumn{6}{|c|}{ Personalization } \\
\hline $\begin{array}{l}\text { The service providers always give me the information } \\
\text { that I am looking for }\end{array}$ & 500 & 1 & 5 & 3.88 & 1.019 \\
\hline $\begin{array}{l}\text { It is easy for me to shape the service in the way that I } \\
\text { want it to be }\end{array}$ & 500 & 1 & 5 & 3.91 & 1.028 \\
\hline $\begin{array}{l}\text { Modifications on the flight information like time, } \\
\text { seating and level can be done easily without troubles }\end{array}$ & 500 & 1 & 5 & 4.12 & .966 \\
\hline I can track my usage of the website & 500 & 1 & 5 & 3.94 & .884 \\
\hline $\begin{array}{l}\text { I can save all my information on the website through a } \\
\text { wiser name and password }\end{array}$ & 500 & 1 & 5 & 4.04 & 1.023 \\
\hline $\begin{array}{l}\text { provides me with different options for payment, } \\
\text { delivering and/or returning items }\end{array}$ & 500 & 1 & 5 & 4.02 & .915 \\
\hline Valid N (listwise) & 500 & & & & \\
\hline
\end{tabular}

Table 3: Variables' Analysis

\begin{tabular}{|l|c|r|r|r|r|}
\hline & $\mathrm{N}$ & \multicolumn{1}{c|}{ Minimum } & \multicolumn{1}{c|}{ Maximum } & \multicolumn{1}{c|}{ Mean } & \multicolumn{1}{c|}{ Std. Deviation } \\
\hline Intention & 500 & 1.00 & 5.00 & 4.0600 & .84839 \\
\hline Site & 500 & 1.00 & 5.00 & 4.0468 & .82921 \\
\hline Information & 500 & 1.00 & 5.00 & 3.8903 & .79748 \\
\hline Accessibility & 500 & 1.00 & 5.00 & 3.7967 & .85915 \\
\hline Communication & 500 & 1.00 & 5.00 & 3.9275 & .80928 \\
\hline Reliability & 500 & 1.00 & 5.00 & 4.1055 & .82716 \\
\hline Trust & 500 & 1.00 & 5.00 & 4.1485 & .75893 \\
\hline Responsiveness & 500 & 1.00 & 5.00 & 4.0573 & .65270 \\
\hline Personalization & 500 & 1.00 & 5.00 & 3.9833 & \\
\hline Valid N (listwise) & 500 & & & & \\
\hline
\end{tabular}

Through the analysis, the previously set hypotheses were tested using ANOVA and Coefficient tests. Based on results it appeared that all the presented hypotheses were accepted and there was a clear intention to use online booking service for airline organization that is attributed to the service quality indicators. The main hypothesis articulated "E-service Quality Indicators positively influences the customers' intention to use online booking applications" was accepted referring to an R-value of 0.865 , which indicated that when the service quality 
indicators are high customers are most likely to adopt the idea of e-ticketing or online ticket booking.

Table 4: The main hypothesis testing

\begin{tabular}{|c|c|c|c|c|c|c|}
\hline \multicolumn{7}{|c|}{ Model Summary } \\
\hline Model & $\mathrm{R}$ & R Square & \multicolumn{2}{|c|}{ Adjusted R Square } & \multicolumn{2}{|c|}{$\begin{array}{l}\text { Std. Error of the } \\
\text { Estimate }\end{array}$} \\
\hline 1 & .865 & .748 & & .744 & & .42918 \\
\hline \multicolumn{7}{|c|}{ ANOVAa } \\
\hline \multicolumn{2}{|l|}{ Model } & $\begin{array}{l}\text { Sum of } \\
\text { Squares }\end{array}$ & Df & Mean Square & $\mathrm{F}$ & Sig. \\
\hline \multirow[t]{3}{*}{1} & Regression & 268.719 & 8 & 33.590 & 182.357 & .000 \\
\hline & Residual & 90.441 & 491 & .184 & & \\
\hline & Total & 359.160 & 499 & & & \\
\hline \multicolumn{7}{|c|}{ Coefficientsa } \\
\hline \multirow{2}{*}{\multicolumn{2}{|c|}{ Model }} & \multicolumn{2}{|c|}{$\begin{array}{l}\text { Unstandardized } \\
\text { Coefficients }\end{array}$} & $\begin{array}{l}\text { Standardized } \\
\text { Coefficients }\end{array}$ & \multirow[t]{2}{*}{$\mathrm{t}$} & \multirow[t]{2}{*}{ Sig. } \\
\hline & & B & $\begin{array}{l}\text { Std. } \\
\text { Error }\end{array}$ & Beta & & \\
\hline \multirow[t]{9}{*}{1} & (Constant) & .338 & .131 & & 2.587 & .010 \\
\hline & Site & .343 & .049 & .335 & 6.939 & .000 \\
\hline & Information & .155 & .048 & .146 & 3.214 & .001 \\
\hline & Accessibility & .001 & .033 & .001 & .034 & .973 \\
\hline & Communication & -.017 & .040 & -.016 & -.431 & .667 \\
\hline & Reliability & .024 & .034 & .023 & .700 & .484 \\
\hline & Trust & .431 & .038 & .420 & 11.353 & .000 \\
\hline & Responsiveness & .205 & .048 & .183 & 4.294 & .000 \\
\hline & Personalization & -.230 & .045 & -.177 & -5.171 & .000 \\
\hline
\end{tabular}

As for the sub-hypotheses; it appeared from the analysis that all 8 sub-hypotheses were accepted and all service quality indicators influence customers' intention to use the service; however, it appeared through analysis that the most influential indicator of service quality was Site Features which was tested using linear regression analysis, with the R value of 0.794 ., it was confirmed that independent variable and dependent variable are strongly correlated. With 29.133 as the value of $t$ at 0.05 significant at (0.05), it was confirmed that Site Features positively influences the customers' intention to use online booking applications.

Table 5: The Site Features variable testing

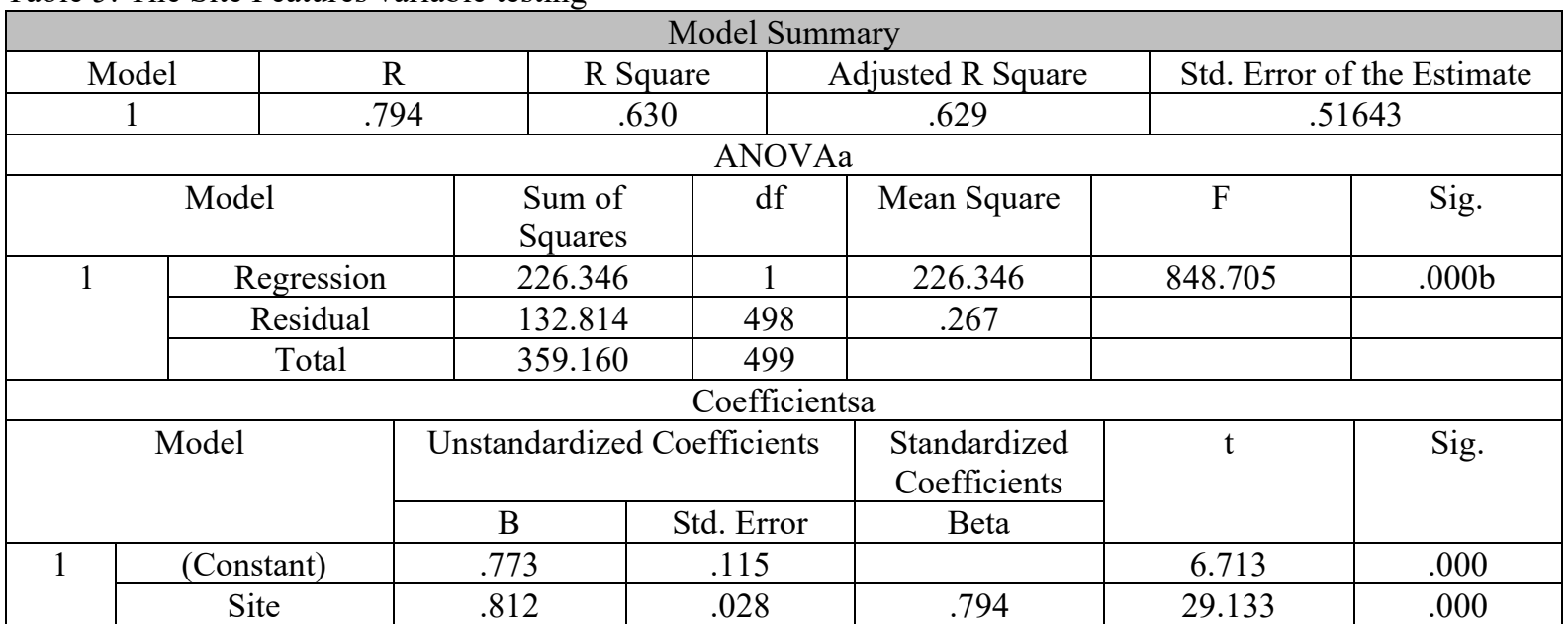

This result was directly followed in influence by the variable of trust which was tested through linear regression analysis 
Table 6: The Trust variable testing

\begin{tabular}{|c|c|c|c|c|c|c|c|}
\hline \multicolumn{8}{|c|}{ Model Summary } \\
\hline \multicolumn{2}{|c|}{ Model } & $\mathrm{R}$ & R Square & \multicolumn{2}{|c|}{ Adjusted R Square } & \multicolumn{2}{|c|}{ Std. Error of the Estimate } \\
\hline & & .79 & .623 & \multicolumn{2}{|l|}{.623} & \multicolumn{2}{|c|}{.52112} \\
\hline \multicolumn{8}{|c|}{ ANOVA } \\
\hline \multicolumn{3}{|c|}{ Model } & Sum of Squares & Df & Mean Square & $\mathrm{F}$ & Sig. \\
\hline \multirow[t]{3}{*}{1} & \multicolumn{2}{|c|}{ Regression } & 223.922 & 1 & 223.922 & 824.57 & .000 \\
\hline & \multicolumn{2}{|c|}{ Residual } & 135.238 & 498 & .272 & & \\
\hline & \multicolumn{2}{|c|}{ Total } & 359.160 & 499 & & & \\
\hline \multicolumn{8}{|c|}{ Coefficients } \\
\hline \multirow{2}{*}{\multicolumn{3}{|c|}{ Model }} & \multicolumn{2}{|c|}{ Unstandardized Coefficients } & $\begin{array}{l}\text { Standardized } \\
\text { Coefficients }\end{array}$ & \multirow[t]{2}{*}{$\mathrm{t}$} & \multirow[t]{2}{*}{ Sig. } \\
\hline & & & $\mathrm{B}$ & Std. Error & Beta & & \\
\hline \multirow[t]{2}{*}{1} & \multicolumn{2}{|c|}{ (Constant) } & .700 & .119 & & 5.870 & .000 \\
\hline & \multicolumn{2}{|c|}{ Trust } & .810 & .028 & .790 & 28.72 & .000 \\
\hline
\end{tabular}

With the R value of 0.790 , it was confirmed that independent variable and dependent variable were strongly correlated. Again, with 28.715 as the value of $t$ at 0.05 significant at $(0.05)$, it was confirmed that trust positively influences the customers' intention to use online booking applications. In the 3rd rank came the variable of responsive which was also tested using linear regression analysis.

Table 7: The Responsiveness variable testing

\begin{tabular}{|c|c|c|c|c|c|c|}
\hline \multicolumn{7}{|c|}{ Model Summary } \\
\hline Model & $\mathrm{R}$ & R Square & \multicolumn{2}{|c|}{ Adjusted R Square } & \multicolumn{2}{|c|}{$\begin{array}{l}\text { Std. Error of the } \\
\text { Estimate }\end{array}$} \\
\hline 1 & .749 & .562 & \multicolumn{2}{|c|}{.561} & \multicolumn{2}{|c|}{.56228} \\
\hline \multicolumn{7}{|c|}{ ANOVAa } \\
\hline \multicolumn{2}{|r|}{ Model } & $\begin{array}{l}\text { Sum of } \\
\text { Squares }\end{array}$ & Df & Mean Square & $\mathrm{F}$ & Sig. \\
\hline \multirow[t]{3}{*}{1} & Regression & 201.714 & 1 & 201.714 & 638.019 & .000 \\
\hline & Residual & 157.446 & 498 & .316 & & \\
\hline & Total & 359.160 & 499 & & & \\
\hline \multicolumn{7}{|c|}{ Coefficientsa } \\
\hline \multirow{2}{*}{\multicolumn{2}{|c|}{ Model }} & \multicolumn{2}{|c|}{$\begin{array}{l}\text { Unstandardized } \\
\text { Coefficients }\end{array}$} & $\begin{array}{l}\text { Standardized } \\
\text { Coefficients }\end{array}$ & \multirow[t]{2}{*}{$\mathrm{t}$} & \multirow[t]{2}{*}{ Sig. } \\
\hline & & $\mathrm{B}$ & $\begin{array}{l}\text { Std. } \\
\text { Error }\end{array}$ & Beta & & \\
\hline \multirow[t]{2}{*}{1} & (Constant) & .661 & .137 & & 4.828 & .000 \\
\hline & Responsiveness & .838 & .033 & .749 & 25.259 & .000 \\
\hline
\end{tabular}

With the $\mathrm{R}$ value of 0.749 , it was confirmed that independent variable and dependent variable were strongly correlated. Again, with 25.259 as the value of $t$ at 0.05 significant at (0.05), it was confirmed that Responsiveness positively influences the customers' intention to use online booking applications. The variable of information came in the 4th rank scoring an $\mathrm{R}$ value of 0.681 , it was confirmed that independent variable and dependent variable were strongly correlated and 20.733 as the value of $t$ at 0.05 significant at $(0.05)$, it was confirmed that Information positively influences the customers' intention to use online booking applications. 
Table 8: The Information variable testing

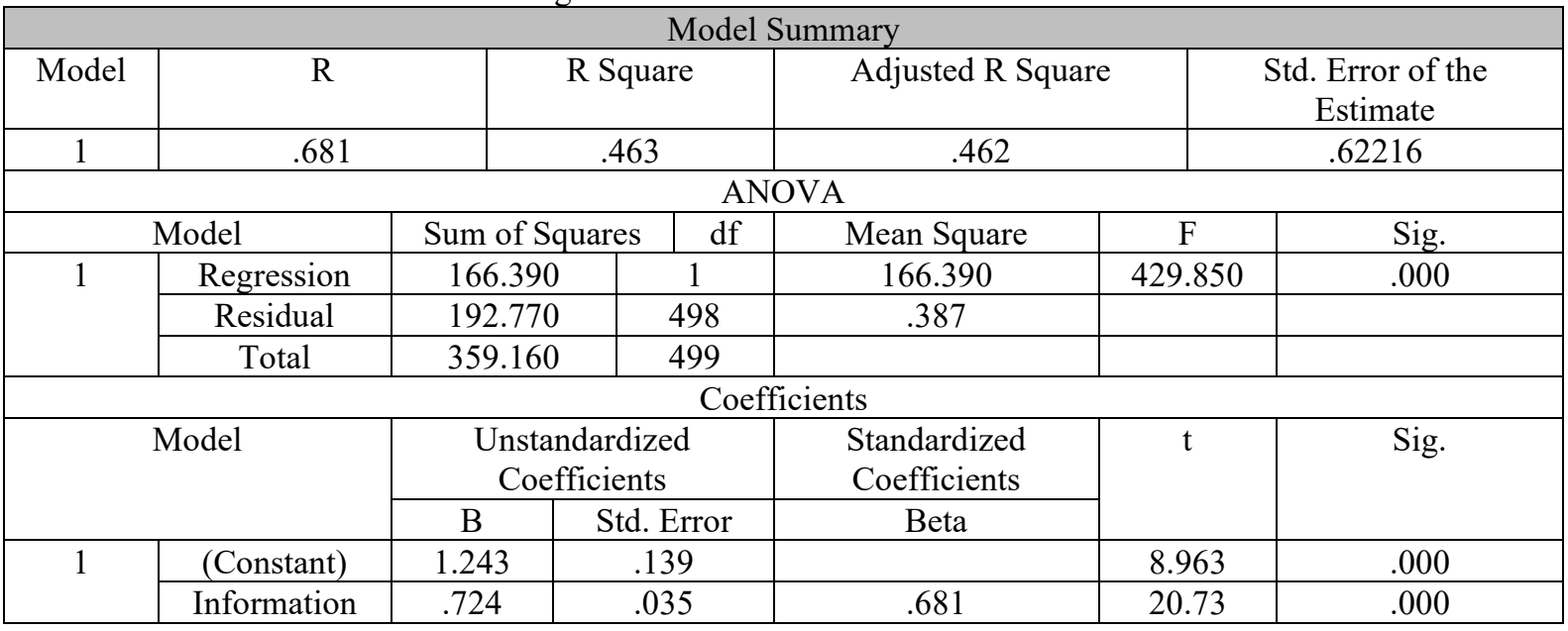

With the $\mathrm{R}$ value of 0.547 , it was confirmed that independent variable and dependent variable were moderately correlated. Again, with 14.569 as the value of $t$ at 0.05 significant at $(0.05)$, it was confirmed that Accessibility positively influences the customers' intention to use online booking applications.

Table 9: The Accessibility variable testing

\begin{tabular}{|c|c|c|c|c|c|c|}
\hline \multicolumn{7}{|c|}{ Model Summary } \\
\hline Model & $\mathrm{R}$ & R Square & \multicolumn{2}{|c|}{ Adjusted R Square } & \multicolumn{2}{|c|}{$\begin{array}{l}\text { Std. Error of the } \\
\text { Estimate }\end{array}$} \\
\hline 1 & .547 & .299 & \multicolumn{2}{|c|}{.297} & \multicolumn{2}{|c|}{.71111} \\
\hline \multicolumn{7}{|c|}{ ANOVA } \\
\hline \multicolumn{2}{|c|}{ Model } & $\begin{array}{l}\text { Sum of } \\
\text { Squares }\end{array}$ & $\mathrm{df}$ & Mean Square & $\mathrm{F}$ & Sig. \\
\hline \multirow[t]{3}{*}{1} & Regression & 107.336 & 1 & 107.336 & 212.264 & .000 \\
\hline & Residual & 251.824 & 498 & .506 & & \\
\hline & Total & 359.160 & 499 & & & \\
\hline \multicolumn{7}{|c|}{ Coefficients } \\
\hline \multirow{2}{*}{\multicolumn{2}{|c|}{ Model }} & \multicolumn{2}{|c|}{$\begin{array}{l}\text { Unstandardized } \\
\text { Coefficients }\end{array}$} & $\begin{array}{l}\text { Standardized } \\
\text { Coefficients }\end{array}$ & \multirow[t]{2}{*}{$\mathrm{t}$} & \multirow[t]{2}{*}{ Sig. } \\
\hline & & B & $\begin{array}{l}\text { Std. } \\
\text { Error }\end{array}$ & Beta & & \\
\hline \multirow[t]{2}{*}{1} & (Constant) & 2.010 & .144 & & 13.940 & .000 \\
\hline & Accessibility & .540 & .037 & .547 & 14.569 & .000 \\
\hline
\end{tabular}

With the $\mathrm{R}$ value of 0.618 , it was confirmed that independent variable and dependent variable were moderately correlated. Again, with 17.528 as the value of $t$ at 0.05 significant at $(0.05)$, it was confirmed that Communication positively influences the customers' intention to use online booking applications.

Table 10: The Communication variable testing

\begin{tabular}{|c|c|c|c|c|c|c|}
\hline \multicolumn{7}{|c|}{ Model Summary } \\
\hline Model & $\mathrm{R}$ & R Square & \multicolumn{2}{|c|}{ Adjusted R Square } & \multicolumn{2}{|c|}{ Std. Error of the Estimate } \\
\hline 1 & .618 & .382 & \multicolumn{2}{|c|}{.380} & \multicolumn{2}{|c|}{.66785} \\
\hline \multicolumn{7}{|c|}{ ANOVA } \\
\hline \multicolumn{2}{|r|}{ Model } & $\begin{array}{l}\text { Sum of } \\
\text { Squares }\end{array}$ & df & Mean Square & $\mathrm{F}$ & Sig. \\
\hline \multirow[t]{3}{*}{1} & Regression & 137.038 & 1 & 137.038 & 307.239 & .000 \\
\hline & Residual & 222.122 & 498 & .446 & & \\
\hline & Total & 359.160 & 499 & & & \\
\hline \multicolumn{7}{|c|}{ Coefficients } \\
\hline \multirow{2}{*}{\multicolumn{2}{|c|}{ Model }} & \multicolumn{2}{|c|}{$\begin{array}{l}\text { Unstandardized } \\
\text { Coefficients }\end{array}$} & $\begin{array}{l}\text { Standardized } \\
\text { Coefficients }\end{array}$ & \multirow[t]{2}{*}{$\mathrm{t}$} & \multirow[t]{2}{*}{ Sig. } \\
\hline & & B & $\begin{array}{l}\text { Std. } \\
\text { Error }\end{array}$ & Beta & & \\
\hline \multirow[t]{2}{*}{1} & (Constant) & 1.517 & .148 & & 10.239 & .000 \\
\hline & Communication & .648 & .037 & .618 & 17.528 & .000 \\
\hline
\end{tabular}


With the $\mathrm{R}$ value of 0.59 , it was confirmed that independent variable and dependent variable were moderately correlated. Again, with 16.294 as the value of t at 0.05 significant at (0.05), it was confirmed that Reliability positively influences the customers' intention to use online booking applications

Table 11: The Reliability variable testing

\begin{tabular}{|c|c|c|c|c|c|c|c|c|}
\hline \multicolumn{9}{|c|}{ Model Summary } \\
\hline \multicolumn{2}{|c|}{ Model } & \multicolumn{2}{|l|}{$\mathrm{R}$} & R Square & \multicolumn{2}{|c|}{ Adjusted R Square } & \multicolumn{2}{|c|}{ Std. Error of the Estimate } \\
\hline \multicolumn{2}{|c|}{1} & \multirow[t]{2}{*}{.590} & \multicolumn{2}{|c|}{.348} & & .346 & \multicolumn{2}{|c|}{.68587} \\
\hline \multicolumn{8}{|c|}{ ANOVA } & \\
\hline \multicolumn{3}{|c|}{ Model } & \multicolumn{2}{|c|}{ Sum of Squares } & Df & Mean Square & $\mathrm{F}$ & Sig. \\
\hline \multirow[t]{3}{*}{1} & \multicolumn{2}{|c|}{ Regression } & \multicolumn{2}{|c|}{124.894} & 1 & 124.894 & 265.499 & $.000 \mathrm{~b}$ \\
\hline & \multicolumn{2}{|c|}{ Residual } & 234.2 & & 498 & .470 & & \\
\hline & \multicolumn{2}{|c|}{ Total } & 359.1 & & 499 & & & \\
\hline \multicolumn{9}{|c|}{ Coefficients } \\
\hline \multirow{2}{*}{\multicolumn{3}{|c|}{ Model }} & \multicolumn{3}{|c|}{$\begin{array}{l}\text { Unstandardized } \\
\text { Coefficients }\end{array}$} & $\begin{array}{c}\text { Standardized } \\
\text { Coefficients }\end{array}$ & \multirow[t]{2}{*}{$\mathrm{t}$} & \multirow[t]{2}{*}{ Sig. } \\
\hline & & & B & & Error & Beta & & \\
\hline \multirow[t]{2}{*}{1} & & & 1.546 & & 57 & & 9.825 & .000 \\
\hline & & & .612 & & 38 & .590 & 16.294 & .000 \\
\hline
\end{tabular}

However, the least influential variable appeared to be personalization which scored an $\mathrm{R}$ value of 0.504 appeared

Table 12: The Personalization variable testing

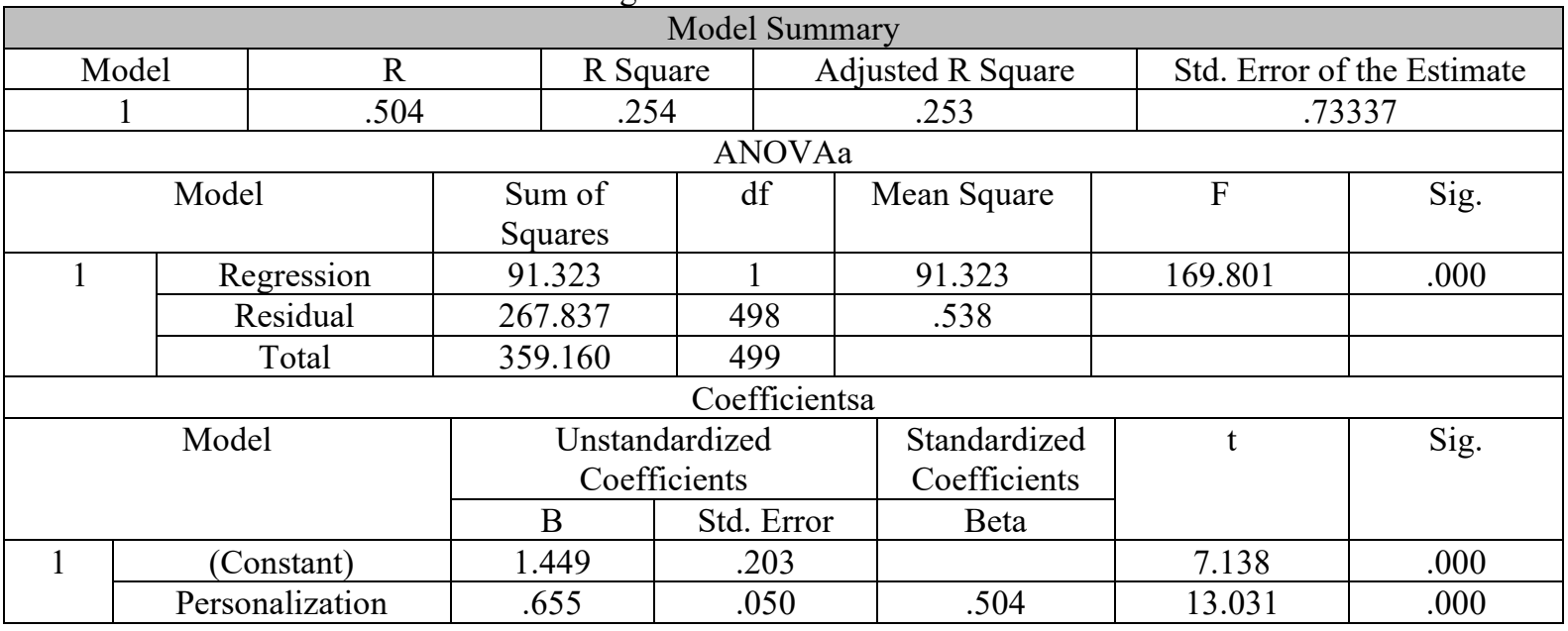

it was confirmed that independent variable and dependent variable were moderately correlated. Again, with 13.031 as the value of $t$ at 0.05 significant at $(0.05)$, it was confirmed that Personalization positively influences the customers' intention to use online booking applications, the following figure showed the difference in variables' influence as according to analysis:

Figure2: Influence of E-Service Quality Indicators on Intention to Use

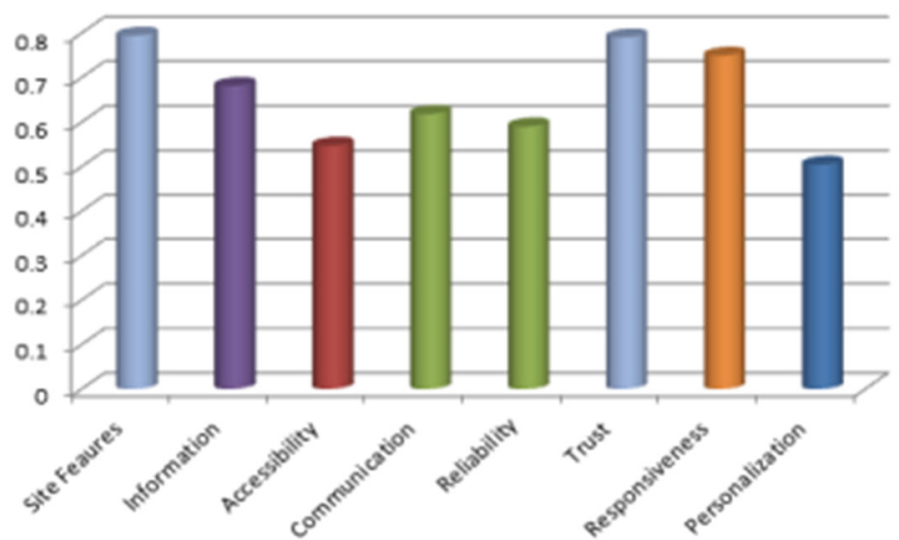

Results of Analysis uncovered a good level of awareness regarding e-ticketing services among chosen sample of study. It appeared that Kuwaiti individuals were familiar with the 
Concept of e ticketing and they had full understanding of e-service quality indicators' meanings and determinants. In addition to that, analyzing the demographic revealed that majority of sample have used e-ticketing at least 3-4 times a year which can refer to a good perception of travelers regarding the convenient use of eticketing. Looking back at results; and seeing that site features appeared to be the most influential variable of eservice quality indicators it can be said that site features includes colors, themes, design, ease of use, platform and all characteristics of a site that make it either attractive to users or too complicated to be used. Using a complex website as according to $\mathrm{Xu}$ (2017) can influence customers' intention to use the site as it may take longer time from them to digest the way it works and ends up needing more time to browse than to go and get the service from the real location. Also, Al-Qeisi et al. (2014) agreed with the same idea arguing that website degree of easiness that is attributed to design and looks can interfere with customers' behavior; authors stated that complicated websites can be very frustrating especially for individuals who are not experts in online purchasing and not user friendly with technology.

In the second rank of influence there appeared trust, this variable is known to have a major influence on customers especially when it comes to online purchasing of items, which includes giving personal or financial information like credit card numbers and payment portals. Many scholars agreed with this argument and focused on the importance of developing trust among customers in order to guarantee full and most beneficial use of online website or booking or purchase. Vejacka and Štofa (2017) agreed on the same idea referring to trust as the most important aspect that defines the customers' intention to use e-service that involves payment and giving out financial information. Also, Skvarciany and Jurevičienè (2018) agreed on the importance of trust in developing users' intention to use an online service. Trust is not only important to online shopping websites; it is also important to all banks which present e-banking services in order to develop their customers' willing to use the service, they have to develop their trust in the provider and the website

\section{Conclusion and Recommendations}

Generally speaking a service must be able to meet lots of criteria in order to gain the satisfaction of customers; that is for the regular service, but when it comes to e-services especially those which require online payments through giving financial information online then there are a deep need to meet all the required indicators of quality that makes a customer willing to deal with the service in a smooth approach that based on trust and comfort. People are very sensitive regarding their personal information; they deal in a sensitive way when it comes to paying money online and handing out credit cards numbers and passwords. E-service quality indicators are among the strategies that guarantee a well-built base for organizations to gain more customers who have the intention to use the service.

E-services in general are a complicated approach to get a certain service; it is based on gaining a service or an item without the need to move from a place to another, it is more of buying an abstract service and pay for it ahead. From that point, organization must pay extra attention to the quality of the service that is being provided online and though the use of website, it involves making the websites more appealing to others regardless of their experience in using technology, in addition to that trust and security are factors that help customer develop better perspective regarding the online service that they gain.

Based on results, discussion and conclusion; current study recommended the following:

- Being smart and mannered when it comes to website features is important but not to the degree that increases the degree of complexity of a website and makes it hard to be followed. Just keep the website easy and simple.

- E-service doesn't diminish the importance of the human factor. Even organizations that are basing their service on internet and technology still need their employees to be polite, smart and willing to offer help in a good and professional approach.

\section{References}

Abdullateef, A. O., Iwu, C. G., Kareem, O., \& Manzuma-Ndaaba, N. M. (2018). Determining customer continuous online usage intention in the airline industry. Research and investment management implications.

Alatawy, K. (2015). Consumer Search Behaviour and Adoption of Online Booking of Travel Services in Saudi Arabia.

AlBalushi, T., Ali, S., Ashrafi, R., \& AlBalushi, S. (2016). Accessibility and Performance Evaluation of E-Services in Oman Using Web Diagnostic Tools. International Journal of u-and e-Service, Science and Technology, 9(7), 9-24.

Al-Hawary, S. I. S., \& Al-Smeran, W. F. (2016). Impact of electronic service quality on customers satisfaction of Islamic banks in Jordan. International Journal of Academic Research in Accounting, Finance and Management Sciences, 7(1), 170-188.

Al-Qeisi, K., Dennis, C., Alamanos, E., \& Jayawardhena, C. (2014). Website design quality and usage behavior: Unified Theory of Acceptance and Use of Technology. Journal of Business Research, 67(11), 2282-2290.

Al-Refaie, A., Bata, N., Eteiwi, D., \& Jalham, I. (2014). Examining Factors that Affect Passenger's Overall 
Satisfaction and Loyalty: Evidence from Jordan Airport. Jordan journal of mechanical \& industrial engineering, 8(2).

Beneke, J., Acton, A., Richardson, D., \& White, F. (2011). E-service quality: An investigation of its key dimensions and the discriminatory power in the residential property sector. Acta Commercii, 11(1), 75-87.

Byambaa, B., \& Chang, K. (2012). The influence of factors of online purchase on customer satisfaction in Mongolian Airlines. International Proceedings of Economics Development and Research, 57(15), 80-85.

Clemes, M. D., Gan, C., Kao, T. H., \& Choong, M. (2008). An empirical analysis of customer satisfaction in international air travel. Innovative Marketing, 4(2), 50-62.

Kim, S., Kim, J., \& Park, S. (2017). The effects of perceived value, website trust and hotel trust on online hotel booking intention. Sustainability, 9(12), 2262.

Kurniawan, B. (2010). Factors affecting customer satisfaction in purchase Decision on ticket online: a case study in air asia.

Malagas, K. N., Kourousis, K. I., Baxter, G., Nikitakos, N., \& Gritzalis, S. (2013). The Introduction of Innovative Services in a State Owned Airline: A Case Study of an IT Migration Project. Journal of technology management \& innovation, 8(2), 74-83.

Nath, A., \& Zheng, L. (2004). Perception of service quality in E-commerce: An analytical study of Internet auction sites.

Qteishat, M. K., Alshibly, H. H., \& Al-ma'aitah, M. A. (2014). The impact of e-ticketing technique on customer satisfaction: An empirical analysis. JISTEM-Journal of Information Systems and Technology Management, 11(3), 519-532.

Skvarciany, V., \& Jurevičienė, D. (2018). Factors Influencing Individual Customers Trust in Internet Banking: Case of Baltic States. Sustainability, 10(12), 4809.

Swaid, S. I., \& Wigand, R. T. (2009). Measuring the quality of e-service: scale development and initial validation. Journal of Electronic Commerce Research, 10(1), 13-28.

Vejacka, M., \& Štofa, T. (2017). Influence of security and trust on electronic banking adoption in Slovakia.

Weinelt, B., \& Moavenzadeh, J. (2017). Digital Transformation Initiative: Aviation, Travel and Tourism Industry. In Geneva, Switzerland: World Economic Forum.

$\mathrm{Xu}, \mathrm{X}$. (2017). The effects of website quality on customer satisfaction, use intention, and purchase intention: A comparison among three types of booking channels. 